\title{
Critical Review of The Curriculum for Islamic Education Management Study Program on Graduate Program
}

\author{
M. Munadi \\ Islamic Education Study Program \\ Faculty of Islamic Education and Teachers' Training \\ IAIN Surakarta \\ munadimahdiputra@gmail.com
}

\begin{abstract}
The study aims to describe the differences among the curriculum of Islamic Education Management Study Program at UIN Maliki Malang, IAIN Sheikh Nurjati Cirebon and STAI Diponegoro. Content analysis method using critical studies was applied in this study. The data were taken from the website of those three universities. The results indicate that the curriculum of Islamic Education Management Study Program at STAI Diponegoro had only one course of education management while IAIN Sheikh Nurjati had two courses of education management. Meanwhile, the courses of education management at UIN Maliki had the contents variously and intensively.
\end{abstract}

Keywords-Curriculum, Islamic Education Management, course

\section{Introduction}

Tri Dharma Perguruan Tinggi, known as Three Pillars of Tertiary Education for higher education consisting of research, teaching, and community services can be implemented through diploma level, undergraduate and graduate program. The major functions, teaching and research are dominant. Whitehead States the universities are schools of education, and schools of research [1]. Higher education functions as the place to both educate and do research. Manuel Castells as stated by John Brennan, Roger King and Yann Lebeau said First, universities have historically played a major role as ideological apparatuses, expressing the ideological struggles present in all societies. Second, they have always been mechanisms of selection and socialization of dominant elites. Third, the generation of knowledge, often seen as their most important function, is actually - according to Castells - a relatively minor one, with functions of scientific research often assumed by specialized national institutes (in Europe and many developing countries) or within in-house laboratories of private firms (for example, Japan). Fourth, the most traditional - and today the most frequently emphasized function of universities is the training of a skilled labor force (what Castells calls the "professional university") [2].
To implement the role of advancing the science can be conducted through undergraduate and graduate programs. The graduate programs are currently held by all Islamic Higher education (PTKI), both State Islamic Higher education (PTKIN) and Private Islamic Higher education (PTKIS). The Data of PTKI rank shows the number of graduate programs as the following table:

Table.1. Numbers of Graduate Program in PTKI

\begin{tabular}{|l|l|l|l|l|}
\hline PTKI & Master Degree & $\%$ & Doctoral Degree & $\%$ \\
\hline PTKIN & 111 & 69 & 18 & 82 \\
\hline PTKIS & 52 & 31 & 4 & 18 \\
\hline Total & 163 & 100 & 22 & 100 \\
\hline
\end{tabular}

a. (Source Diktis, 2012 modified)

The table shows that graduate program nearly $50 \%$ is held by PTKIN rather than PTKIS. School of Education organized by postgraduate program can be seen on the following table:

Table. 2. Study Program in State Islamic Higher Education

\begin{tabular}{|l|c|c|c|c|}
\hline \multicolumn{1}{|c|}{ Study Program } & $\begin{array}{c}\text { Master } \\
\text { Degree }\end{array}$ & $\%$ & $\begin{array}{c}\text { Doctoral } \\
\text { Degree }\end{array}$ & $\%$ \\
\hline Islamic Religion Education & 13 & 34 & 0 & 0 \\
\hline Islamic Education & 10 & 26 & 2 & 40 \\
\hline Tradition of Islamic Education & 1 & 2,6 & 0 & 0 \\
\hline Islamic Education Sciences & 2 & 5,3 & 0 & 0 \\
\hline $\begin{array}{l}\text { Islamic Elementary School } \\
\text { Education }\end{array}$ & 3 & 7,9 & 0 & 0 \\
\hline $\begin{array}{l}\text { Management of Islamic } \\
\text { Education }\end{array}$ & 4 & 11 & 1 & 20 \\
\hline Islamic Education Study & 1 & 2,6 & 0 & 0 \\
\hline $\begin{array}{l}\text { Islamic Kindergarten School } \\
\text { Education }\end{array}$ & 1 & 2,6 & 0 & 0 \\
\hline Arabic Language Education & 2 & 5,3 & 1 & 20 \\
\hline English Language Education & 1 & 2,6 & 0 & 0 \\
\hline General Islamic Education & 0 & 0 & 1 & 20 \\
\hline Total Number & 38 & 100 & 5 & 100 \\
\hline
\end{tabular}

Study programs on Education conducted by PTKIN are very varied. Islamic Religion Education study program has the biggest number among the others then followed by Islamic Education study program. Each study program has the focus on Islamic Education Management. The same case happens to 
PTKIS and PTKIN in conducting both undergraduate and graduate program as the following table:

Table.3. Study program in Private Islamic Higher education

\begin{tabular}{|l|c|c|c|c|}
\hline Study Program & $\begin{array}{c}\text { Master } \\
\text { Degree }\end{array}$ & $\%$ & $\begin{array}{c}\text { Doctoral } \\
\text { Degree }\end{array}$ & $\%$ \\
\hline Islamic Religion Education & 6 & 20 & 0 & 0 \\
\hline Islamic Education & 17 & 57 & 1 & 50 \\
\hline Islamic Education Sciences & 1 & 3,3 & 0 & 0 \\
\hline Management of Islamic Education & 4 & 13 & 0 & 0 \\
\hline Arabic Language Education & 2 & 6,7 & 0 & 0 \\
\hline Psychology of Islamic Education & 0 & 0 & 1 & 50 \\
\hline Total Number & 30 & 100 & 2 & 100 \\
\hline
\end{tabular}

The table shows that the condition happens in PTKIS is similar to PTKIN, as an example when PTKIS conducts Islamic education study program in general then focusing on Islamic education management. The existence of Islamic Education Management needs intensive study on its curriculum as the goal is to make the institution better than before, The higher education curriculum has become the site for a fascinating clash of epistemologies as well as value and educational and the other priorities [3].

\section{THE CURRICULUM IN HIGHER EDUCATION}

According to Stobie (in Thushari Welikala), the concept of curriculum refers to a diversity of elements which can be separately identified as contributing to the learning process [4]. The idea indicates that the concept of curriculum refers to the diversity of elements that can be identified separately as contribution to the learning process. Meanwhile, Curriculum consists of five aspects, according to Owen Hicks [5]:

1. what is to be learnt - content

2. why it is to be learnt - rationale and underlying philosophy

3. how it is to be learnt - process

4. when it is to be learnt - structure of the learning process

5. how the learning will be demonstrated and achievement assessed."

The statement above shows that the curriculum includes on what will be learned - content based, why should be learned the rationale and philosophy underlying the curriculum, how it should be learned - a process, when it should be learned - the structure of the learning process including the consideration of how the learning will be demonstrated and the achievement will be assessed.

In the context of higher education, according to Harry Hubball, and Neil Gold, curriculum as a contextually-bound and coherent program of study that consists of multiple integrated and progressively challenging course learning experiences which are carefully designed to develop student's knowledge, abilities and skills [6].
The statement above emphasized that the curriculum as contextual program that is bound and coherent study program consisting several integrated courses progressively and designed carefully to develop the knowledge, skills and abilities of students.

The curriculum for higher education level is based on the concept of education from UNESCO that consists of learning to know, learning to do, learning to live together, and learning to be. To implement toes four concepts above, Slattery's identified three main elements of postmodern curriculum: (a) a focus on community cooperation rather than corporate competition, (b) a holistic process perspective rather than separate parts, and (c) a multilayered, interdisciplinary curriculum, which includes the integration of theology. (Shawn L. Oliver and Eunsook Hyun) [7].

The statement above indicates that the higher education curriculum in the era of post-modern must have three main elements, namely: (a) focusing on community cooperation rather than competition company, (b) the perspective of holistic process and not the parts separately, and (c) layered, interdisciplinary curriculum, which includes the integration of theology.

M. Hanafi states the poor curriculum makes the quality of State Islamic Higher Education does not meet the peoples' expectations, and the contribution to the development of Islam is still considered to be less significant [8]. Meanwhile, Kraince found that the curriculum of State Islamic Higher Education makes students take part of the community by becoming agents for brainstorming the progressive ideas in Indonesian [9].

This study used descriptive qualitative using text as the unit of analysis. It aims to understand the phenomenon in a text about the curriculum that is being implemented to each Islamic Education Management study program at UIN Maulana Malik Ibrahim, Sheikh IAIN Nurjati Cirebon, and STAI Diponegoro Tulungagung. Document analysis is used to collect the data. Then they were analyzed using descriptive analysis model.

\section{FINDINGS AND DISCUSSION}

The study initially examines the curriculum of graduate study program for Islamic Education Management Study Program, and also examines the MP curriculum that provides opportunities to take Islamic Education Management courses of Islamic education. The scope of study is not only on PTKIN but also PTKIS.

There are 4 PTKIN conducting postgraduate Program of MPI Study Program: UIN Maulana Malik Ibrahim Malang, 
IAIN Syekh Nurjati Cirebon, IAIN Surakarta, STAIN Batusangkar, and 1 PTKIS (STAI Diponegoro Tulungagung). The data found on the website said only 4 universities provided the information about Islamic Education Management. They are UIN Maulana Malik Ibrahim, IAIN Syekh Nurjati and STAI Diponegoro. The information obtained from STAIN Batusangkar only for the 2nd and 3rd semester, meanwhile IAIN Surakarta did not provide the information on curriculum.

The basic curriculum is given as the foundation to understand the teachings of Islam and the contents of management. The courses consist of Qur'an, Hadith, English and Arabic. The detailed explanation of the courses are different between UIN Maulana Malik Ibrahim, IAIN Syekh Nurjati and STAI Diponegoro. The comparison is as follows:

Table.4. Comparison on the Basic Curriculum

\begin{tabular}{|c|c|c|c|}
\hline No & $\begin{array}{l}\text { UIN Maulana Malik } \\
\text { Ibrahim }\end{array}$ & $\begin{array}{l}\text { IAIN Syekh } \\
\text { Nurjati }\end{array}$ & $\begin{array}{c}\text { STAI } \\
\text { Diponegoro }\end{array}$ \\
\hline 1. & - & - & $\begin{array}{l}\text { Basic } \\
\text { philosophy }\end{array}$ \\
\hline 2. & Quran Studies & $\begin{array}{l}\text { Tafsir and } \\
\text { Hadits }\end{array}$ & $\begin{array}{l}\text { Tafsir and } \\
\text { Hadits of } \\
\text { Education }\end{array}$ \\
\hline 3. & Hadits studies & - & - \\
\hline 4. & $\begin{array}{l}\text { English (Manuscript } \\
\text { studies) }\end{array}$ & Bahasa Inggris & $\begin{array}{l}\text { Bahasa } \\
\text { Inggris }\end{array}$ \\
\hline 5. & $\begin{array}{l}\text { Arabic (Manuscript } \\
\text { studies) }\end{array}$ & Bahasa Arab & Bahasa Arab \\
\hline 6. & $\begin{array}{l}\text { Approaches on Islamic } \\
\text { Studies }\end{array}$ & $\begin{array}{l}\text { Islamic Study } \\
\text { Methodology }\end{array}$ & - \\
\hline 7. & Islamic Philosophy & $\begin{array}{l}\text { Filsafat Ilmu } \\
\text { dan Metode } \\
\text { Berpikir }\end{array}$ & Filsafat Ilmu \\
\hline 8. & $\begin{array}{l}\text { Islamic Civilization } \\
\text { History }\end{array}$ & $\begin{array}{l}\text { Civilization } \\
\text { History }\end{array}$ & - \\
\hline 9. & - & $\begin{array}{l}\text { History of } \\
\text { Islamic } \\
\text { Intellectual }\end{array}$ & $\begin{array}{l}\text { History of } \\
\text { Islamic } \\
\text { Education }\end{array}$ \\
\hline
\end{tabular}

The table shows that in general there is no differences of the principle relating to the basic curriculum of Islamic Education Management for 2 PTKINs and 1 PTKIS. However, the researcher found the differences were on several courses, i.e. IAIN Sheikh Nurjati had more courses on history specifically. The course of history of education in both IAIN Sheikh Nurjati and STAI Diponegoro were similar. Foreign language courses were found on the website of each university, but UIN Maliki had more contextual in naming the foreign language courses rather than 2 other observed universities.

Regarding with the courses about Islamic studies, UIN Maliki separated on the course Qur'an and Hadith, but IAIN Sheikh Nurjati and STAI Diponegoro combined the course of Tafsir and Hadith. Although the courses were combined, STAI
Diponegoro still relates with educational course. IAIN Sheikh Nurjati developed the courses of history into two general categories: History of Thought and Islamic civilization and History of Islamic Intellectual, while UIN Maulana Malik Ibrahim had only one course of history given to graduate students namely Islamic civilization History, while STAI Diponegoro did not offer the course of history,

The above basic courses were developed into several specific courses. The researcher found that The goal was not balanced because there were differences in the curriculum as the following table:

Table.5. Curriculum Development on Basic Courses

\begin{tabular}{|l|l|l|l|}
\hline No. & \multicolumn{1}{|c|}{$\begin{array}{c}\text { UIN Maulana } \\
\text { Malik Ibrahim }\end{array}$} & \multicolumn{1}{|c|}{$\begin{array}{c}\text { IAIN Syekh } \\
\text { Nurjati }\end{array}$} & STAI Diponegoro \\
\hline 1. & $\begin{array}{l}\text { Research } \\
\text { Methodology } \\
\text { Management of } \\
\text { Education }\end{array}$ & $\begin{array}{l}\text { Research } \\
\text { Methodology }\end{array}$ & $\begin{array}{l}\text { Research } \\
\text { Methodology }\end{array}$ \\
\hline 2. & - & $\begin{array}{l}\text { Information } \\
\text { Technology }\end{array}$ & $\begin{array}{l}\text { Education } \\
\text { Technology }\end{array}$ \\
\hline 3. & - & - & $\begin{array}{l}\text { Islamic } \\
\text { Philosophy }\end{array}$ \\
\hline 4. & - & - & $\begin{array}{l}\text { Sociology of } \\
\text { Education }\end{array}$ \\
\hline 5 & - & - & $\begin{array}{l}\text { Psychology of } \\
\text { Islamic Education }\end{array}$ \\
\hline 6. & - & - & $\begin{array}{l}\text { Islamic Education } \\
\text { Methodology }\end{array}$ \\
\hline
\end{tabular}

The table above shows that to develop the courses of management, students were given the courses related to the research based. UIN Maliki provided the courses of research methods, but not for the other two universities.

To develop the research based, information technology conducted by IAIN Sheikh Nurjati is truly needed. The students can adapt to both internet and technology as the result is to provide students having the ability to understand the technology. This is very important as to develop the students' management skills. Therefore, students will always upgrade the latest information on the management education.

The comparison above shows that some courses were not relevant for the development of Islamic Education Management especially in STAI Diponegoro. It provided the courses (educational sociology, educational psychology, and Islamic educational methodology) which should be given to the pre-service teacher, not to the manager of education. Those three courses are relevant for the students taking Islamic Religion Education study program. 
The classification of two major courses above was given specifically into the content of Management for Education as follow:

Table.6. Major Course on Management for Education

\begin{tabular}{|c|l|l|l|}
\hline No & \multicolumn{1}{|c|}{$\begin{array}{l}\text { UIN Maulana } \\
\text { Malik Ibrahim }\end{array}$} & IAIN Syekh Nurjati & STAI Diponegoro \\
\hline 1. & $\begin{array}{l}\text { Planning for } \\
\text { Islamic education }\end{array}$ & $\begin{array}{l}\text { Planning for } \\
\text { education }\end{array}$ & $\begin{array}{l}\text { Management for } \\
\text { Education Strategy }\end{array}$ \\
\hline 2. & $\begin{array}{l}\text { Leading for } \\
\text { Islamic Education }\end{array}$ & $\begin{array}{l}\text { Leading for } \\
\text { Education }\end{array}$ & $\begin{array}{l}\text { Islamic leadership } \\
\text { theory and model) }\end{array}$ \\
\hline 3. & $\begin{array}{l}\text { Management for } \\
\text { Curriculum and } \\
\text { learning }\end{array}$ & - & $\begin{array}{l}\text { Developing for } \\
\text { Islamic Curriculum }\end{array}$ \\
\hline 4. & $\begin{array}{l}\text { Educational } \\
\text { Supervision }\end{array}$ & $\begin{array}{l}\text { Educational } \\
\text { Supervision }\end{array}$ & $\begin{array}{l}\text { Educational } \\
\text { Supervision }\end{array}$ \\
\hline 5. & $\begin{array}{l}\text { Islamic Education } \\
\text { Policy Studies }\end{array}$ & $\begin{array}{l}\text { Analysis for } \\
\text { Education Policy }\end{array}$ & $\begin{array}{l}\text { Management for } \\
\text { Education Quality }\end{array}$ \\
\hline 6. & $\begin{array}{l}\text { Management for } \\
\text { Islamic Education } \\
\text { Quality }\end{array}$ & $\begin{array}{l}\text { Management for } \\
\text { Education }\end{array}$ \\
\hline 7. & - & $\begin{array}{l}\text { Management for } \\
\text { Education }\end{array}$ & - \\
\hline
\end{tabular}

The Comparison on the table above shows that the major courses of management were similar as seen from their names. It is interesting for the case of planning courses. STAI Diponegoro has given the name of the courses not in term of planning, but in term of Management for Education strategy. This case is more interesting because the students did not just make an educational planning specifically, but also generally.

However there are some weaknesses in STAI Diponegoro that was caused by the limited number of management courses and several factors such as the institution is more emphasizing on the courses to prepare pre-service teachers than pre-service managers of educational institutions.

UIN Maliki develops the ability to manage the education, students were given elective course. As shown by the table, the UIN Maliki gives courses, as follows:

Table.7. Elective courses

\begin{tabular}{|l|l|l|l|}
\hline No & $\begin{array}{l}\text { UIN Maulana Malik } \\
\text { Ibrahim }\end{array}$ & \multicolumn{1}{|c|}{$\begin{array}{c}\text { IAIN Syekh } \\
\text { Nurjati }\end{array}$} & \multicolumn{1}{c|}{$\begin{array}{c}\text { STAI } \\
\text { Diponegoro }\end{array}$} \\
\hline 1. & $\begin{array}{l}\text { Management for } \\
\text { Education costs }\end{array}$ & $\begin{array}{l}\text { Management for } \\
\text { Education costs }\end{array}$ & - \\
\hline 2. & $\begin{array}{l}\text { Management for } \\
\text { Supporting education }\end{array}$ & - & - \\
\hline 3. & $\begin{array}{l}\text { Management for } \\
\text { classroom and Student }\end{array}$ & - & - \\
\hline 4. & $\begin{array}{l}\text { Management for } \\
\text { running education and } \\
\text { training }\end{array}$ & - & - \\
\hline 5. & $\begin{array}{l}\text { Management for } \\
\text { public relation in } \\
\text { Education }\end{array}$ & $\begin{array}{l}\text { Management for } \\
\text { Marketing in } \\
\text { Education }\end{array}$ & - \\
\hline 6. & $\begin{array}{l}\text { Management for } \\
\text { Human resources in } \\
\text { Education }\end{array}$ & $\begin{array}{l}\text { Management for } \\
\text { staff in } \\
\text { Education }\end{array}$ & $\begin{array}{l}\text { Management } \\
\text { for Human } \\
\text { resources in } \\
\text { Education }\end{array}$ \\
\hline
\end{tabular}

The elective Courses in STAI Diponegoro are minimal. It is only one course. Meanwhile IAIN Sheikh Nurjati has two courses. Courses in UIN Maliki had a variety of management courses of education. There is a difference between UIN Maliki and IAIN Sheikh Nurjati, ie the course Management for Public Relations and Management for Human resources in Education were taught in UIN Maliki. IAIN Sheikh Nurjati offered Management for Human resources in Education

Although both those courses were linear but they will have an impact on the specific course.

The course of Management for public relation in Education was taught at UIN Maliki. IAIN Sheikh Nurjati cirebon offered under the name Management for Marketing in Education. All the data did not show the optional courses in Educational management related to teaching staff, students, and others.

This research did not lead to an adjustment between the changing needs of the community and curriculum development in graduate program. This is the different case with the findings of research from Fatemeh Havas beigi et al. that Curriculum for Islamic Education Management should refer to: changing in technology and sciences, evolutions of economic and social, alteration of cultural, political changing and globalization. The Curriculum for Islamic Education Management should match the changes where the institution is located [10].

\section{CONCLUSION}

The responds to change the curriculum is required to prepare graduate program curriculum to be better. Moreover, Islamic education becomes more complex and complicated than General education (without the label of Islam). The process of implementing Curriculum for Islamic Education Management indicates that STAI Diponegoro had minimal support. Meanwhile, IAIN Sheikh Nurjati had only two courses. UIN Maliki had shown the good progress to develop the variety of Islamic Education Management courses intensively.

\section{REFERENCES}

[1]. Whitehead, Alfred North (1927). Universities and Their Function. https://webspace.utexas.edu/hcleaver/www/330T/350kPEEwhitehead univfxtable.pdf

[2]. John Brennan, Roger King and Yann Lebeau (2004). The Role of Universities in the Transformation of Societies An International Research Project. London: Centre for Higher Education Research and Information The Open University. www.open.ac.uk/cheri/documents/transf-final-report.pdf

[3]. David Bridges. (2000). Back The Future : The Higher Education Curriculum in The $21^{\text {st }}$ Century. Cambridge Journal of Education, Vol. 30 No. 10,2000 
[4]. Thushari Welikala. (2011). Rethinking International Higher Education Curriculum: Mapping the research landscape. A position paper commissioned and published by Universitas 21 , leading global network of research universities for the 21 st century May 2011

[5]. Owen Hicks (2007). Curriculum in higher education in Australia Hello? in Enhancing Higher Education, Theory and Scholarship, Proceedings of the 30th HERDSA Annual Conference [CD-ROM], Adelaide, 8-11 July.

[6]. Harry Hubball, and Neil Gold. (2007). The Scholarship Of Curriculum Practice And Undrgraduate Program Reform: TheoryPractice Integration www.cte.hawaii.edu/.../HH_NG_Ch1_2.pdf

[7]. Shawn L. Oliver and Eunsook Hyun. (2011) Comprehensive curriculum reform in higher education: collaborative engagement of faculty and administrators Journal of Case Studies in Education. Journal of Case Studies in Education. Journal of Case Studies in Education 2 (2011): 1-20. www.aabri.com/manuscripts/10649.pdf

[8]. M. Hanafi. (2014). Pengembangan Kurikulum Perguruan Tinggi Agama Islam. Jurnal Islamuna Volume 1 Nomor 2 Desember 2014. download.portalgaruda.org/article.php?...PENGEMBANGAN\%20..

[9]. Kraince, Richard G. (2007). Islamic higher education and social cohesion in Indonesia. Springer Link. September 2007, Volume 37, Issue 3, pp 345-356. http://link.springer.com/article/10.1007/s11125008-9038-1

[10]. Fatemeh Havas beigi, Mohammad Reza Keramatib, Azam Ahmadi. (2011). The quality curriculum evaluation in postgraduate studies of Educational Management and Planning in the public Universities of Tehran City. 3rd World Conference on Educational Sciences - 2011 . Procedia Social and Behavioral Sciences 15 (2011) 3723-3730. http://www.sciencedirect.com/science/article/pii/S187704281100909 8 